\title{
THE TEACHER OF TECHNICAL VRITING IN CANADA: A PROFILE
}

\author{
Results of a Survey Conducted by the \\ Canadian Association of Teachers of Technical Writing
}

\author{
Report Prepared by: \\ Ron $S$ Blicq \\ Vice President, CATTW \\ Red River Community College
}

\begin{abstract}
A 1984 survey shows that teachers of technical writing at Canadian universities and two-year colleges work under different constraints. University professors tend to be more autonomous but often feel they are the "poor relations" of the English or French department. College instructors work in a more positive environment and tend more often to draw on their colleges technical departments to increase the relevance of their technical writing courses. Both groups feel the classes they face are too large for effective teaching, and college instructors generally teach twice as many hours per week as their university peers. Both groups also indicate that more emphasis could be placed on professional development.
\end{abstract}

\section{INTRODUCTION}

The ided for a survey of CATTW members evolved from discussion I had with Joan Pavelich (President of CATTW) at the University of British Columbia in May 1983. We both felt that teachers of technical writing would benefit from learning about each other, the kind of work technical writing teachers are doing, and the conditions they work under. I agreed to develop a survey form and Joan agreed to distribute it among CATTW members.

The questionnaire was developed in the fall of 1983, circulated among several CATTW members to identify whether it covered appropriate topics, and then translated into French so that Quebec teachers also could take part. This was a slow process, so that the questionnaire was not ready for distribution until April 1984.

Rather than limit distribution solely to CATTW members, we decided also to distribute the questionnaire to delegates attending two 
Conferences: the STC/ABCA Regional Conference held at Douglas College, New Westminster, BC, at the end of April 1984, and the CATTW conference held as part of The Learneds conference at Guelph, Ontario, in May 1984. Copies of the questionnaire were mailed to all CATTW members in June 1984.

The survey form was introduced by a short explanation of its purpose, which I am repeating here.

The purpose of this survey is to enable teachers of technical writing to exchange information on the environments in which they teach, identify the focus of other instructors' programs, and learn a little more about the "what" and "how" of our subject as it is taught in Canada. (Although the term "technical writing" is used throughout this questionnaire, it includes any practical communication/report writing course taught to students within a specific discipline, even though the course may be identified by a title such as "business writing.") Many such teachers/instructors/professors work in English departments where the subject they teach is only a fragment of a much broader program, which in many cases causes them to feel very much part of a minority. For them, to obtain data on what others are doing means going to a conference or seminar, which in today's budget-conscious environment can be very difficult to do.

(This paragraph alone evoked the following response: "I feel very lost in the backwoods.")

I have received 34 questionnaires spread over eight months. Although this may not seem a high response, in light of the questionnaire's length (43 questions spread over 10 pages) I consider it a reasonable return and would like to commend those who responded for taking the time to complete the form in detail. Fortunately, there is a cross-section of responses from across the country, including three from French-speaking universities in Quebec. And, once I began to tabulate the returns, I soon realized that, even with our small sample, a distinct pattern was forming; a pattern that was corroborated as each fresh survey arrived.

\section{TABULATING THE RESPONSES}

Recording the responses and analysing them proved to be a lengthy process, since the questionnaire had not been designed for computer assessment. This proved to be an asset because the variety of responses, and the different circumstances that respondents had to report, demanded more than just manually tabulating checkmarks. Several respondents commented that the questionnaire proved difficult to fill out because 
"...many of the terms used seem based on assumptions not valid at (our) college. Ours is a service department, based on the teaching of language, literature and communications to a wide range of programs in Health Sciences, Business, Applied Arts, Technology and Applied Science. Thus 'Technical Writing' and 'Technical Communication,' in the narrow sense, represent only a small proportion of our overall commitment."

"...our emphasis on technical writing is part of the socialization of a professional (physiotherapist). Personally I am interested in learning more about the teaching of technical writing and the components of it."

"...I found the wording of many of the questions at odds with the way we operate. We have considerable autonomy in what we do and how we operate."

Another respondent listed a stream of questions:

"I'd like to know how most technical writers in industry became technical writers. Those I know drifted in from a variety of backgrounds, just as I did into teaching. Do most technical writing teachers use texts, or make up their own? (There has been a flood of technical writing texts on the market.) Someone here suggested a program to train technical writers..."

One major difference showed up early in the tabulations: responses from teachers of technical writing at universities were at variance with the responses from teachers at community colleges and technical institutes. This caused me to divide the responses to many of the questions into two groups, as the results below show. For this reason I am defining three terms $I$ will be using frequently throughout the report:

Technical writing

University

College
Any form of writing which concentrates on a specific discipline, such as medical, biological, and chemical sciences, electronics, forestry, business, nursing, or instrumentation.

Any institution conferring a degree on its graduates.

Any institution conferring a diploma or certificate on its graduates.

The results below are divided into four categories, each preceded by a brief profile: 
--The technical writing teacher.

- The technical writing subject.

- -The technical writing student.

--The technical writing teacher's administration.

I have generally refrained from commenting on the results, assuming that my role is primarily to present the information and leave readers to make their own interpretations. Among the results, however, I have interspersed comments that individual respondents provided, since they offer a useful look at aspects the survey form did not particularly question.

\section{THE TECHNICAL WRITING TEACHER}

Profile

Only one of every five "English" and "French" department members teaches technical writing. He or she holds an M.A. degree, teaches 8-9 or 17-18 hours per week (depending on whether at a university of college), faces classes fifty percent larger than he or she considers ideal for a good learning environment, is paid between $\$ 25,000$ and $\$ 45,000$ a year, and quite. likely does private consulting as an extracurricular activity.

\section{Survey Responses}

Thirty universities and colleges provided information on staff complement and backgrounds. They listed 158 staff members who teach technical writing (approximately 5 per institution), out of a total English, French, or Communication department complement of 462 professors and instructors. Of the $158,9(5.5 \%)$ hold technical degrees, $12(7.5 \%)$ hold Maths or Science degrees, $109(69 \%)$ hold Arts degrees, and 28 (18\%) hold other degrees. Their experience of business and industry is divided fairly evenly, with 42 (27\%) having worked in a business environment and 37 (23\%) having worked in a technical industry. Forty-six (31\%) say they have had technical writing experience, either working in industry or as consultants.

The qualifications demanded by universities and colleges for their teachers of technical writing are:

--At universities, an M.A. is required but a Ph.D. is preferred. (However, respondents from three universities stated that a Ph.D. is a requirement.)

- At colleges, all respondents stated that a B.A. is a requirement but an M.A. is preferred. 
No respondents stated that a technical degree was an optional preference, and only one mentioned a Science degree as an acceptable qualification. Yet one respondent added the qualification:

"(Our) college has been guilty of the philosophy that anyone can teach English. While we prefer to hire people with B.A.'s in English and some Business or Industrial experience, we've also hired sociologists, journalists, a classics major, a philosophy major, and an engineer."

About three-quarters of the respondents said that, as teachers of technical writing, they are part of an English/French/Communication department. The remainder are either part of (10\%) or attached to (15\%) a technical department. One of the latter, who is part of a university engineering department, wrote:

"There is only one teacher of Technical Communication, with assistance from the faculty in terms of workshops. The first year, four engineering faculty members served as workshop leaders, although they had no expertise in the field. This past year, I had three graduate teaching assistants (Engineering), but here again they lacked expertise. I'm hopeful I'll be able to hire a parttime assistant this fall; someone with an English/Consulting background."

Salary ranges are generally higher for university professors who teach technical writing than they are for college instructors, with the former averaging $\$ 34,500$ to $\$ 45,250$ a year, and the latter $\$ 25,000$ to $\$ 41,900$ a year. The lowest and highest salaries quoted were:

$\begin{array}{lcl} & \text { University } & \text { College } \\ \text { Lowest salary } & \$ 25,000 & \$ 22,000 \\ \text { Highest salary } & \$ 60,000 & \$ 48,000\end{array}$

(The university salary range is based on a rather small response, university professors seemingly being hesitant to mention what they are paid.)

Two questions sought to identify whether professors and instructors chose to teach technical writing, and how much of their teaching hours were assigned to the subject. At both universities and colleges, $40 \%$ of those teaching technical writing asked to do so. The remaining $60 \%$ were assigned to teach the subject. Almost all college instructors indicated they preferred the assignment (only one respondent said he or she would prefer not to teach technical writing). At universities, however, only half the professors assigned to teach technical writing agreed it was their preference. A college instructor added: 
"Of the 12 who now teach technical writing (or business writing), none were really hired to teach it. All were conscripted from other duties. Seven or eight of us have learned to enjoy the courses and have worked hard to become proficient at them. Personally, I find it a very rewarding subject to teach and I take considerable pride in the quality of my graduates."

Six respondents said they teach technical writing one hundred percent of the time. For the remaining 28 respondents, technical writing is only part of their teaching commitment, ranging from less than $5 \%$ up to $80 \%$ and averaging $45 \%$.

The survey asked respondents to state how many hours they teach a week, how many weeks they teach a year, and how many students they face in each class (averages were requested). This data was used to form a "teaching load profile," first by calculating the hours taught in a year (hours/week $X$ weeks/year) and then by calculating the total number of students faced in a year (hours/year $X$ students/class). The results are shown in Figure 1 below.

\begin{tabular}{|c|c|c|c|c|c|}
\hline \multirow{2}{*}{\multicolumn{2}{|c|}{ Universities (9 responses) }} & Average & Median & Minimum & Maximum \\
\hline & & & & & \\
\hline A & Teaching hours/week & 8.5 & 9 & 3 & 20 \\
\hline B & Teaching weeks/year & 28.7 & 26 & 24 & 40 \\
\hline C & Teaching hours/year $(A \times B)$ & 244 & 234 & -- & -- \\
\hline D & Average class size & 39.5 & 35 & 23 & 90 \\
\hline E & Contact hours/year $(\mathrm{C} \times \mathrm{D})$ & 9,638 & 8,190 & -- & - \\
\hline & 1 leges (14 responses) & & & & \\
\hline A & Teaching hours/week & 17.5 & 18 & 13.5 & 21 \\
\hline B & Teaching weeks/year & 33.2 & 33.5 & 26 & 45 \\
\hline C & Teaching hours/year ( $A \times B)$ & 581 & 603 & -- & -- \\
\hline D & Average class size & 24 & 25 & 18 & 30 \\
\hline$E$ & Contact hours/year $(\mathrm{C} \times \mathrm{O})$ & 13,944 & 15,075 & -- & -- \\
\hline
\end{tabular}

Figure 1. Comparison of Teaching Loads 
As one would expect, the weekly teaching load and length of teaching year are significantly higher for college instructors $(17.5$ hours/week and 33.2 weeks per year) than for university professors (8.5 hours/week and 28.7 weeks/year), resulting in an annual hourly teaching load for instructors that is almost three times greater than for professors. This is offset by class size, however, which for college instructors averages 24 students and for university professors averages nearly 40 students. Consequently, the differential is reduced when individual student contact hours are calculated (i.e., the total number of students a teacher of technical writing faces over a one-year period), with college instructors facing roughly fifty percent more students than university professors $(14,035$ vs 9,150 individual student contact hours).

Teachers' perception of what would constitute an ideal-size technical writing class proved to be $35-40 \%$ less than the actual-size classes they encounter. (The two questions concerning ideal and suggested class sizes were widely separated in the survey form, and placed unobtrusively among other questions so that the one response would not directly influence the other.) Generally, the suggested and actual class sizes faced by university professors are $55 \%$ larger than those suggested and faced by college instructors:

\section{Universities Colleges}

$\begin{array}{lll}\text { Suggested "ideal" class size } & 25 & 16 \\ \text { Actual class size (average) } & 39.5 & 24\end{array}$

The length of the academic year varies widely, stretching from a minimum of just under 7 months to a full 11 months. As one would expect, college instructors teach a longer year than college instructors:

Length of Academic Year

7 months

8 months

9 months

10 months

11 months

\section{Universities Colleges}

$40 \%$

$5 \%$

$50 \%$

$40 \%$

$10 \%$

$30 \%$

$20 \%$

$5 \%$

Approximately $40 \%$ of university professors use marking assistants to assess their students' technical writing assignments. College 
instructors, however, are almost unanimous in stating that they rarely use marking assistants (only two respondents indicated that they "occasionally" do so). A university professor writes:

"At ...., M.A. graduate students do much of the teaching of technical writing, usually (but not always) under the direction of a professor. The students attend a one-hour lecture per week (given, usually, by the professor) and then attend a two-hour lab in which they actually write. These labs have 20-25 students and are taught by graduate students."

Half of the teachers polled say they also teach technical writing outside their university or college. The professors seem to act independently of their universities, but the college instructors indicate they teach outside courses both as college representatives and as independent individuals. As one university teacher wrote:

"I have organized courses (on behalf of the university) for industry and government in the old days, but I now do it as a consultant--more profit!"

More college instructors (65\%) than university professors (40\%) do private consulting in technical communication.

Two questions attempted to assess administrators' support of such extracurricular activities. University respondents indicated that their administrations either "encourage" or "accept" that professors should do private consulting. College teachers of technical writing, however, say that their administrations are less supportive, and break the administrations' support into:

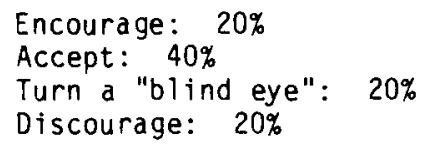

When the survey asked if the administration supports taking technical writing courses into industry as a university or college offering, the responses showed that only $40 \%$ of the institutions polled engage in off-campus teaching.

\section{THE TECHNICAL WRITING SUBJECT}

Profile

At universities most emphasis is placed on writing formal technical reports, while at colleges greater emphasis is placed on writing business correspondence and short reports. At universities the English/ French department or individual professors tend to define the technical 
writing curriculum and choose specific subject topics, whereas at colleges the English/Communication department frequentiy enlists advice from the college's technical departments before selecting the curriculum and topics. In both institutions advice is rarely sought from industry.

Technical writing is much more likely to be a mandatory subject at colleges than at universities, and colleges are more likely to tailor their subject content to suit specific technical disciplines.

Survey Responses

Courses (which at some institutions are referred to as "subjects") in technical writing are identified by a variety of titles. Most popular at universities are "Technical Writing" and "Report Writing." At colleges the most popular title is "Technical Communication," probably indicating that writing is not the only communications topic taught. Other course titles mentioned by respondents were:

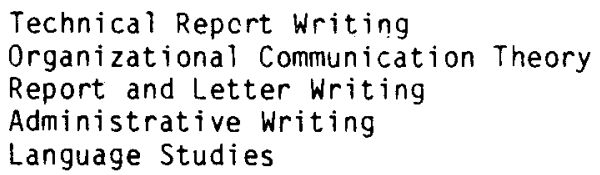

There also were several titles under the general "Communication" heading:

\author{
Communication \\ Industrial Communication \\ Business Communication \\ Health Communication
}

One college respondent wrote:

"My department has been variously named 'Liberal Studies,'

'Literature and Language,' 'Humanities,' and 'Language Studies.'

The names reflect the changing philosophy of the department from a liberal arts focus to a language skills focus."

University respondents were almost unanimous in saying that technical writing represents between 0 and $20 \%$ of the total "English" or "French" courses taught by their departments. At colleges, however, technical writing comprises a much greater department commitment:

$80-100 \%$ of language skills teaching at $25 \%$ of the colleges $40-60 \%$ at $20 \%$ of the colleges

$20-40 \%$ at $7 \%$ of the colleges

$0-20 \%$ at $48 \%$ of the colleges 
The same college instructor commented:

"While Technical Writing has been offered by my department for about 14 years, its growth came about more from the demands of our Technical and Business programs and from employers of our graduates than from a willingness to offer these courses."

In their technical writing courses, university professors place most emphasis on the long formal report and less emphasis on business correspondence and short reports. College instructors, however, tend to stress shorter reports and then place equal emphasis on business correspondence and the long formal report. No one seems to place significant emphasis on spelling. A summary of the responses is shown in Figure 2 .

\section{Topic}

Technical correspondence

Short reports

The long formal report

Instructions and descriptions

Illustrations

Language development (paragraph and sentence structure)

Spelling

Oral communication

Job application letter and resume

\section{University}

$9 \%$

$14 \%$

$36 \%$

$8 \%$

$5 \%$

$14 \%$

$2 \%$

$7 \%$

$5 \%$
College $18 \%$ $24 \%$ $19 \%$ $6 \%$ $6 \%$ $7 \%$ $2 \%$ $8 \%$ $10 \%$

Figure 2. Emphasis placed on specific topics.

A respondent also commented (perhaps implying that insufficient time is allotted to technical communication):

"I maintain that Technical Writing must be a writing course (given our 15-week semester length). While I enthusiastically support oral communication courses, I strongly oppose combining the writing with the speaking."

University professors seem to keep curriculum design mostly "in house," with about $40 \%$ saying it was done by the English/French department and almost half saying "I designed the curriculum myself." As one added in a notation: 


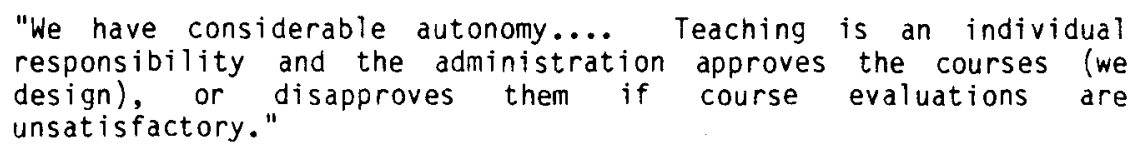

At colleges, the curriculum is designed either by the Language Arts/ Communication department, the appropriate technical department, or as a collaborative effort between the two departments. The responses are summarized below.

\section{Curriculum Designer}

English (or French) department

Technical department

Collaboration between both departments

Individual teacher

\section{University}

$41 \%$

$9 \%$

$5 \%$

$45 \%$
College

$41 \%$

$12 \%$

$47 \%$

0

But an instructor also appended this comment:

"At our college technical writing is regarded as an English skill involving language compression and syntax. The format of technical writing is taken very lightly, since we believe that format is simply a matter of information. We also believe that "Good English" is adaptable to any format, and that its form varies only to accommodate audience."

University respondents stated that either the English/French department or the individual technical writing professors had the primary influence on the choice of subject topics and curriculum design. At colleges, however, although the English/Communication department had the main influence, the technical departments and advisory boards together made a significant contribution. Surprisingly, all respondents indicated that industry (i.e., the potential employers of the majority of technical graduates) had only $4 \%$ influence. The specific responses are summarized in the following table.

Body Influencing Topic Selection

English, French or Communication Department

Technical Department

Advisory Board

Industry

Individual Instructor

Other

\section{University}

$31 \%$

$15 \%$

$2 \%$

$4 \%$

$40 \%$

$8 \%$

\section{College}

$52 \%$

$23 \%$

$17 \%$

$4 \%$

$4 \%$

0 
A marked difference occurred between universities and colleges in the responses to the question: "Do you offer a general course in technical communication or do you tailor courses for specific disciplines (e.g., forestry, computer engineering, pharmacy)?":

\section{Universities Colleges}

$\begin{array}{lcc}\text { Offer a general course } & 80 \% & 20 \% \\ \text { offer dedicated courses } & 15 \% & 70 \% \\ \text { offer both } & 5 \% & 10 \%\end{array}$

Clearly, university professors primarily offer general courses while college instructors primarily offer dedicated (tailored) courses.

More college instructors than university professors try to integrate their teaching of technical writing with a technical course being taught by a "core" (technical) subject instructor:

\section{Degree of Integration}

No integration

Only a small amount of integration

Major report integrated

Considerable integration

Lectures and writing labs still dominate as the primary method of instruction: $87 \%$ at colleges and $98 \%$ at universities. At colleges, the remaining $13 \%$ of the time is used for:

Individual consulting: $7 \%$

Seminars and guest speakers: $4 \%$

Cooperative methods (time in industry): $2 \%$

Disparate responses were evoked by the question: "At your university or college, is technical communication a mandatory or optional subject?" At universities, technical communication tends to be optional while at most colleges it is mandatory:

\section{Universities Colleges}

Mandatory

$40 \%$

$85 \%$

Optional

$60 \%$

$15 \%$ 
Fifty percent of the universities and $67 \%$ of the colleges have prerequisites that must be met before a student can enrol in a technical communication course. These were stated as:

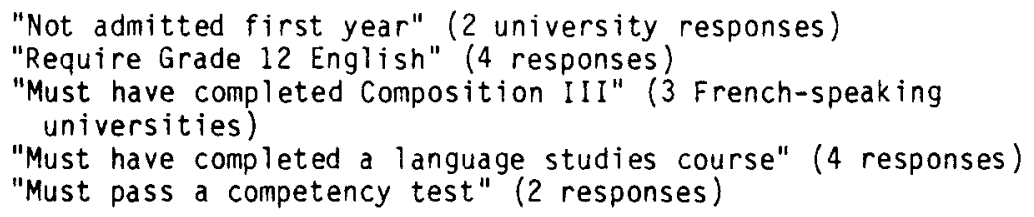

However, only a minority of students enrolling in technical writing courses have to take a pretest: at universities, 25\%; at colleges, $40 \%$. The test may be an English (or French) placement or achievement test, a college entrance test, or a basic English proficiency test. For those who fail the tests, either a remedial course, a learning skills workshop, or individual help is available. (The extent to which this help is available was not solicited by the survey form.)

Do teachers of technical writing require that students type their reports and assignments? Generally, they do, and particularly for their major projects:

$\begin{array}{lcc} & \text { Universities } & \text { Colleges } \\ \text { Require all assignments to be typed } & 7 \% & 40 \% \\ \text { Require major projects to be typed } & 78 \% & 60 \% \\ \text { Do not demand typing } & 15 \% & \end{array}$

Yet, although $50 \%$ of students have access to word processors (WP), very few teachers of technical writing require that their students prepare their assignments on a WP:

Universities Colleges
Not a requirement
$100 \%$
$75 \%$
Required "in a few cases"
0
$25 \%$

However, $10 \%$ of the respondents added a note that they either encourage WP use or that it will "be a requirement next year" (i.e., in 1985).

The final question in this section enquired whether the university, college, or department plans to offer a degree or diploma course in technical writing. There were only four "yes" responses: one university said it is offering a degree course now, and three colleges plan to offer a diploma course in the future. 


\section{THE TECHNICAL WRITING STUDENT}

\section{Profile}

The age of the average technical writing student is 20-21 and, if attending college, he or she likely will have had 1-2 years of full-time work experience (much less work experience if attending university). His or her perception of technical writing as a valuable subject is low at course entry but much higher after the student has completed a technical writing course. Approximately every twelfth student is writing and speaking in English or French as a second language.

\section{Survey Responses}

The question "What programs are your students enrolled in?" applied primarily to colleges, since a standard answer ("Four-year degree") applied to universities. The breakdown of responses from colleges was:

$\begin{array}{lr}\text { One-year certificate } & 45 \% \\ \text { Two-year diploma } & 100 \% \\ \text { Three-year diploma } & 35 \% \\ \text { Four-year degree } & 7 \%\end{array}$

(The total adds up to more than $100 \%$ because most colleges checked more than one answer.)

The average age of students attending both university and college is 20-21. But, because university students attend for three or four years (compared to one or two years for college students), their age at course entry is 12 to 18 months younger than that of their college peers. This is reflected in the responses to a question eliciting details of work experience, which shows that approximately $60 \%$ of college students have had between one and four years of full-time work, whereas only $20 \%$ of university students have held a full-time job:

$\begin{array}{cccc}\text { Previous Work Experience } & \text { Universities } & \text { Colleges } \\ \text { Worked for } 3-4 \text { years } & 0 & 8 \% \\ \text { Worked for } 1-2 \text { years } & 20 \% & 52 \% \\ \text { Part-time work only } & 80 \% & 40 \%\end{array}$

One college respondent commented:

"Many of our students are over 25. This year I would say about $30 \%$ of mine were in that category."

The number of ESL (English as a Second Language) students attending technical writing classes appears to be $60 \%$ greater at colleges than at universities: 


\section{Universities Colleges \\ Number of ESL Students \\ $6.5 \%$ \\ $11 \%$}

Three colleges reported they had as high as $20 \%$ ESL students per class, and one college respondent added: "In some programs over half of the students are ESL students." Yet six universities and colleges reported they have no ESL students in their technical writing classes.

Students' perception of the technical report writing course (as perceived and reported by their teachers) differs between university and college students, particularly before they take the course. University professors state that $70 \%$ of their students feel the course will "probably be of value." College instructors, however, say that $70 \%$ of their students feel the course will only "possibly be of value" or is "just another English course."

But all teachers report that after students have taken a technical report writing course the pendulum swings to the other extreme. Then, $55 \%$ of university students and $70 \%$ of college students apparently view their technical writing course as "an essential part of their technical education." (The remaining $45 \%$ of university students are quoted as still feeling the course will "probably" be of value to their future development.) One respondent commented that:

"Our technical students take courses to be involved in practical technology. They would rather not write at all, but grasp it will probably be an important part of their jobs. But that's not what they want."

Still another teacher wrote:

"We use the IEEE (Institute of Electrical and Electronics Engineers Inc.) as a stimulus for writing as the organization is popular in our college."

\section{THE TECHNICAL WRITING TEACHER'S ADMINISTRATION}

\section{Profile}

Although both university and college administrations support technical writing as a valuable subject, at the university English or French department level this support is much less positive; even negative. College English/Communication departments, however, appear to be more committed to teaching technical writing. Support for professional development in technical writing is perceived to be patchy at best, at both universities and colleges. 


\section{Survey Responses}

Two questions attempted to determine how much each respondent's administration and English/French/Communication department are committed to the philosophy and value of teaching technical writing. Threequarters of both university and college respondents replied that their administrations are either "wholeheartedly" or "generally" supportive (20\% and $55 \%$ respectively). College instructors also said that support is even higher from the English/Communication department (50\% "wholeheartedly" and 45\% "generally" supportive). At universities, however, support from within the English or French department ebbs somewhat, with $35 \%$ claiming that the department treats those who teach technical writing as "poor relations." Two respondents felt so alienated that they paused to write notes:

"(The department) chooses to believe it (technical writing) doesn't exist."

"It (the department) doesn't want to know what's going on."

Another felt strongly enough about the administration to write:

"The most important aspect of Technical Communication as far as our Administration is concerned is having large classes. It believes the more it can pack into a classroom the better."

Oniy four respondents (12\%) said that their university or college pays for teachers' membership in professional societies such as the Canadian Association of Teachers of Technical Writing (CATTW), the Society for Technical Communication (STC), the Professional Communication Society (PCS: a subsociety of the IEEE), or the Association for Business Communication ( $A B C$ : formerly $A B C A$ ). Similarly, only $40 \%$ of universities and colleges pay for their teachers ${ }^{\prime}$ subscriptions to journals on technical writing (and even then seven respondents added that it is only a partial or token subscription).

One of the survey's questions attempted to determine the primary sources of information used by teachers of technical communication to gain expertise in their subject. Most respondents referred to the literature, professional associations, and teachers' peers. The majority of sources listed were:

Textbooks (13 responses)

Professional associations and conferences (8)

Professional journals (5)

Previous personal education (5)

Interacting (counselling) with business and industry (5)

Practical writing experience (5)

Contacts with technical teaching staff (4)

Academic writing for publication (3) 
Administrations' support of professional development (PD) for teachers of technical writing is perceived to be generally more positive at universities than at colleges. As the following table shows, the respondents feel that their administrations are only generally supportive.

\section{Administrative Support of PD}

Encourage PD and support it financially

Encourage PD "generally"

Discourage PD
Universities Colleges

$20 \%$

$25 \%$

$55 \%$

$35 \%$

$10 \%$

(The responses do not add up to $100 \%$ because approximately one-quarter of the respondents checked "not known".) A university professor added:

"Individuals largely decide their own approach to professional development, which may or may not be financially supported."

And a college instructor said:

"We've had little real professional development organized in this department. The college's philosophy seems to be PD for computer use only these days. Two of us now do outside consulting, and two others have in the past, but most of our professional growth comes from texts, from private conversations, and some sharing of materials."

When questioned what types of professional development are most supported by the university's or college's administration (or that the English/French/Communication department becomes involved in), respondents indicated that sending professors and instructors to workshops, seminars, and conferences is more common than bringing in an outside expert or running an in-house professional development seminar. Indeed, the responses clearly show a negative acceptance of running professional development in-house, particularly at the universities.

I am tabulating all four sets of responses, since professional development seems to be a particularly sensitive topic among teachers of technical writing:

\section{Question}

Universities $\quad \underline{\text { Colleges }}$

Does your administration/department send its technical writing teachers to workshops and seminars?

$$
\begin{aligned}
& \text { Regularly or occasionaliy } \\
& \text { Rarely or never }
\end{aligned}
$$

$62 \%$

$38 \%$
$50 \%$

$50 \%$ 
Question

Universities Colleges

Does your administration/department

send its teachers to technical

writing or communications conferences?

$$
\begin{array}{lll}
\text { Regularly or occasionally } & 32 \% & 45 \% \\
\text { Rarely or never } & 68 \% & 55 \%
\end{array}
$$

Does your administration/department bring in outside experts to conduct PD seminars in technical writing?

$\begin{array}{lcc}\text { Regularly } & 0 & 5 \% \\ \text { Occasionally } & 15 \% & 25 \% \\ \text { Rarely } & 15 \% & 20 \% \\ \text { Never } & 70 \% & 50 \%\end{array}$

Do your department members present in-house seminars in specialty areas of technical communication?

$\begin{array}{lcc}\text { Regularly } & 0 & 10 \% \\ \text { Occasionally } & 30 \% & 27 \% \\ \text { Rarely } & 15 \% & 35 \% \\ \text { Never } & 55 \% & 28 \%\end{array}$

Earlier comments by respondents show that some professors and instructors also do consulting to develop their expertise in technical writing.

\section{CONCLUSIONS}

The tabulated results have satisfied the main objective of the survey, in that they enable teachers of technical writing to exchange information on the environments they work in and the focus of their programs. In particular they show that:

--There are differences in the teaching of technical writing between universities and colleges, both in content and approach.

- - Technical writing is taught primarily by teachers with an Arts background. 
--The technical community has greater opportunity to influence the choice of technical writing curriculums at colleges than at universities.

--Classes are larger than most teachers of technical writing feel is conducive to an effective learning environment.

- College instructors of technical writing carry a significantly heavier teaching load than their peers at universities.

--At universities particularly, some teachers of technical writing feel they are working in an unsupportive environment at the department level.

--Support for professional development in the teaching of technical writing is at best spotty.

--Some teachers do consulting in industry to achieve personal professional development.

--Students tend to perceive technical writing--before they enroll in the subject--as a "necessary evil" rather than a valuable component of their technical education.

Although the survey results are based on only a moderate-size sample, the trends are generally clearly defined and can be considered representative of the average environment in which technical writing is taught at Canadian universities and colleges. Ideally, a second survey with a more definitive range of questions should be conducted in, say, three years to show either corroboration of the present results or shifting trends in the perceptions of and attitudes to the teaching of technical writing.

\section{RECOMMENDATION}

I recommend that the executive of the Canadian Association of Teachers of Technical Writing form a small task force to develop a new questionnaire and conduct a more comprehensive survey in 1987.

Ron S Blicq

May 2, 1985

Ron S Blicq is Head, Industrial and Technology Communications, Red River Community College in Winnipeg. He is currently the President of CATTW. 